\title{
Reputasi Auditor sebagai Pemoderasi Pengaruh Opini Audit dan Pergantian Manajemen pada Auditor Switching
}

\author{
Nyoman Ratna Candradewi ${ }^{1}$ \\ Fakultas Ekonomi dan Bisnis \\ Universitas Udayana, Indonesia
}

\author{
Gayatri $^{2}$ \\ Fakultas Ekonomi dan Bisnis \\ Universitas Udayana, Indonesia
}

Surel : ratnacandradw@gmail.com

\section{ABSTRAK}

Pergantian auditor merupakan perilaku yang dilakukan perusahaan klien untuk melakukan perpindahan auditor. Penelitian ini ditujukan untuk mendapat bukti empiris pengaruh opini audit dan pergantian manajemen pada auditor switching dan bagaimana reputasi auditor mampu memoderasi pengaruh opini audit dan pergantian manajemen pada auditor switching. Penentuan sampel penelitian menggunakan metode purposive sampling dengan sampel sebanyak 145 perusahaan. Teknik analisis data yang digunakan adalah analisis regresi logistik dan Moderated Regression Analysis (MRA). Berdasarkan hasil penelitian ini menunjukkan bahwa opini audit dan pergantian manajemen berpengaruh signifikan positif terhadap auditor switching. Namun reputasi auditor tidak mampu memoderasi pengaruh opini audit dan pergantian manajemen pada auditor switching.

Kata Kunci: Opini Audit; Pergantian Manajemen; Reputasi Auditor; Auditor Switching.

\section{Auditor's Reputation as Moderating the Effect of Audit Opinions and Management Substitutionon Auditor Switching}

\begin{abstract}
Auditor turnover is a behavior that the client company does to transfer the auditor. This research aims to obtain empirical evidence of the effect of audit opinion and management change on auditor switching and how the auditor's reputation is able to moderate the influence of audit opinion and management change on auditor switching. Determination of the research sample using purposive sampling method with a sample of 145 companies. Data analysis techniques used are logistic regression analysis and Moderated Regression Analysis (MRA). Based on the results of this study indicate that audit opinion and management change have a significant positive effect on auditor switching. However, the auditor's reputation is unable to moderate the effect of audit opinion and management change on auditor switching.
\end{abstract}

Keywords: Audit Opinion; Change of Management; Auditor Switching; Auditor's Reputation.

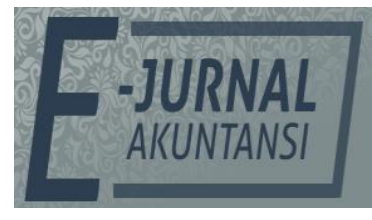

e-ISSN 2302-8556

Vol. 30 No. 10

Denpasar, Oktober 2020

Hal. 2456-2470

DOI:

10.24843/EJA.2020.v30.i10.p02

PENGUTIPAN:

Candradewi, N.R. \& Gayatri.

(2020). Reputasi Auditor sebagai Pemoderasi

Pengaruh Opini Audit dan

Pergantian Manajemen pada

Auditor Switching. E-Jurnal

Akuntansi, 30(10), 2456-2470

RIWAYAT ARTIKEL:

Artikel Masuk:

21 Februari 2020

Artikel Diterima:

12 Juli 2020

Artikel dapat diakses : https://ojs.unud.ac.id/index.php/Akuntansi/index 


\section{PENDAHULUAN}

Laporan keuangan yang disajikan oleh perusahaan merupakan gambaran kondisi keuangan serta hasil kinerja manajemen dalam mengelola perusahaan selama periode tertentu. Manajemen dalam perusahaan berkewajiban menyajikan laporan keuangan untuk menunjukkan hasil kinerja mereka kepada pihak-pihak yang membutuhkan (Widyanti \& Badera, 2016). Banyak pihak yang berkepentingan terhadap laporan keuangan, maka informasi yang disajikan dalam laporan keuangan harus wajar, dapat di percaya dan tidak menyesatkan bagi pemakainya sehingga kebutuhan masing-masing pihak yang berkepentingan dapat terpenuhi (Putra \& Suryanawa, 2016). Sari \& Widanaputra (2016) menyatakan bahwa untuk mengurangi resiko laporan keuangan yang dapat dipengaruhi oleh kepentingan manajemen, maka diperlukan peran akuntan publik atau auditor sebagai pihak yang independen untuk dapat menengahi kedua belah pihak yang memiliki kepentingan berbeda antara manajemen dengan pemilik perusahaan. Keandalan laporan keuangan akan lebih terpercaya jika telah di audit oleh auditor eksternal.

Independensi auditor merupakan kunci utama untuk menilai kewajaran dan keandalan dari laporan keuangan. Independensi ini mutlak harus ada pada diri auditor. Sikap independensi bermakna bahwa auditor tidak mudah dipengaruhi, sehingga auditor akan melaporkan apa yang ditemukannya selama proses pelaksanaan audit (SPAP, 2016). Auditor yang dapat mempertahankan independensinya maka kemungkinan kualitas audit menjadi lebih tinggi dan auditor tidak mudah terpengaruh oleh kepentingan klien (Sima \& Badera, 2018).

Sukadana (2016) menyatakan bahwa terdapat keraguan mengenai independensi auditor terkait hubungan kerja yang panjang antara auditor dan klien kemungkinan menciptakan suatu ancaman terhadap hubungan yang terjalin diantara mereka sehingga dapat mempengaruhi obyektivitas dan independensi auditor. Maka dari itu diperlukan suatu peraturan yang ketat dan jelas untuk mengatur perikatan auditor (Wijaya \& Rasmini, 2015).

Salah satu anjuran agar tetap obyektif adalah dengan menerapkan rotasi wajib auditor (Nasser et al., 2006) karena dapat meningkatkan kemampuan auditor dalam melindungi publik melalui peningkatan kewaspadaan terhadap setiap kemungkinan ketidaklayakan, peningkatan kualitas pelayanan, dan mencegah hubungan yang lebih dekat dengan klien. Adanya rotasi audit ini merupakan awal dari munculnya fenomena pergantian auditor (auditor switching). Auditor switching didefinisikan sebagai pergantian auditor atau kantor akuntan publik (KAP) yang dilakukan oleh perusahaan.

Perusahaan dalam melakukan pergantian KAP dapat terjadi oleh dua alasan yakni karena adanya peraturan pemerintah yang bersifat wajib (mandatory) dan dilakukan atas keinginan perusahaan itu sendiri, maka pergantian ini bersifat sukarela (voluntary).Apabila perusahaan mengganti auditor yang telah mengaudit selama masa yang ditentukan merupakan hal yang wajar dan perusahaan melakukan hal tersebut dikarenakan ingin mematuhi aturan yang berlaku. Pergantian auditor yang terjadi dalam perusahaan diluar ketentuan peraturan pemerintah perlu diketahui faktor 
penyebabnya, karena pergantian yang terlalu sering bisa menimbulkan pertanyaan serta kecurigaan yang berasal dari investor.

Pergantian manajemen menjadi salah satu penyebab perusahaan melakukan pergantian auditor. Pergantian manajemen yang dimaksud dalam hal ini adalah pergantian direksi utama, disebabkan karena keputusan rapat umum pemegang saham atau pihak manajemen berhenti karena kemauannya sendiri (Pradhana \& Suputra, 2015). Apabila perusahaan melakukan perubahan dewan direksi baik komisaris maupun direktur, maka berbagai kebijakan seperti keuangan, akuntansi, dan pemilihan KAP juga akan mengalami perubahan.

Terdapat beberapa penelitian yang mendukung bahwa pergantian manajemen mempengaruhi adanya pergantian auditor atau auditor switching, diantaranya penelitian yang dilakukan oleh Nyakuwanika (2015), Pawitri \& Yadnyana (2015), serta Saputra (2017) yang menyatakan bahwa pergantian manajemen berpengaruh pada auditor switching. Pada penelitian lain terdapat hasil yang berbeda. Hal ini ditunjukkan oleh penelitian dari Ali (2015) yang meneliti pengaruh pergantian manajemen pada auditor switching yang dilakukan di Bahrain Bourse dengan menggunakan kuisioner dalam penelitiannya mendapatkan hasil yang bertolak belakang dimana tidak terdapat pengaruh pergantian manajemen pada auditor switching.

Sama seperti pergantian manajemen, pemberian opini tertentu pada laporan keuangan auditan dianggap memberi pengaruh terhadap motivasi pergantian auditor. Opini audit adalah pernyataan auditor mengenai kewajaran, dalam semua hal yang material, posisi keuangan, hasil usaha dan arus kas entitas tertentu apakah telah sesuai dengan prisip akuntansi berterima umum (Mulyadi, 2016:19). Auditor memiliki tanggung jawab atas pemberian opini terkait dengan kewajaran laporan keuangan perusahaan. Pendapat yang tentunya diharapkan oleh seorang manajemen yaitu opini wajar tanpa pengecualian. Begitu pula sebaliknya, manajemen tidak mengharapkan jika opini yang diberikan yaitu wajar dengan pengecualian (Chow \& Rice, 1982).

Menurut Mohamed \& Habib (2013) opini dari auditor dianggap sebagai indikator kualitas audit apabila auditor menerbitkan opini audit yang sesuai. Ketidaksesuaian muncul ketika auditee merasa tidak sesuai terhadap opini audit dari auditor sehingga dapat memicu salah satu pihak memisahkan diri. Chow \& Rice (1982) menyatakan bahwa perusahaan lebih sering mengganti auditor setelah menerima qualified opinion atas laporan keuangannya karena dapat berdampak pada kemunduran harga saham, kesulitan dalam meningkatkan modal pinjaman, ketidakpercayaan investor, kreditor, dan karyawan terhadap manajemen perusahaan.

Penelitian yang dilakukan oleh Luthfiyati (2016), Nasser et al., (2006), dan Putra \& Suryanawa (2016) juga menyatakan hal yang sama bahwa setelah menerima qualified opinion, perusahaan atau klien akan lebih cenderung mengganti auditornya atau kantor akuntan publiknya. Hal ini bertentangan dengan hasil penelitian yang dilakukan oleh Fajrin (2015) serta Pawitri \& Yadnyana (2015) yang menunjukkan bahwa opini audit tidak berpengaruh pada keputusan perusahaan klien untuk melakukan pergantian auditor. 
Berdasarkan hasil dari penelitian sebelumnya, peneliti tertarik untuk menguji kembali bagaimana pengaruh opini audit dan pergantian manajemen pada perusahaan yang melakukan pergantian auditor. Adanya inkonsistensi hasil penelitian pada penelitian sebelumnya menyebabkan peneliti tertarik untuk meneliti dengan menggunakan variabel moderasi yang dapat mempengaruhi hubungan langsung opini audit dan pergantian manajemen dengan auditor switching. Oleh karena itu peneliti menggunakan reputasi auditor sebagai variabel pemoderasi.

Reputasi auditor digunakan sebagai variabel pemoderasi dalam penelitian ini karena ketika perusahaan melakukan pergantian manajemen dan mendapatkan opini yang tidak sesuai, perusahaan memiliki kemungkinan untuk mengganti auditornya. Perusahaan dalam mengganti auditornya tentunya akan memilih menggunakan auditor yang bereputasi baik, yang ditunjukkan dengan KAP yang berafiliasi dengan KAP big four. Dengan mengganti auditornya menggunakan auditor yang lebih memiliki nama maka reputasi perusahaan juga akan terangkat di mata investor. KAP yang berafiliasi dengan big four dianggap lebih memiliki kualitas yang tinggi dibandingkan dengan KAP non big four. Perusahaan akan lebih memilih KAP big four karena dipandang lebih meningkatkan kredibilitas perusahaan (Agiastuti \& Suputra, 2016).

Menurut Pawitri (2015) dengan memilih kantor akuntan publik (KAP) yang memiliki nama baik maka diharapkan nantinya dapat memberikan reaksi positif bagi pihak-pihak yang ingin berinvestasi sehingga dapat memberikan keuntungan bagi perusahaan. Perusahaan audit yang lebih besar memiliki kualitas audit yang lebih unggul karena mereka berinvestasi lebih banyak dalam bidang audit teknologi dan pelatihan serta cenderung memiliki sumber daya yang kompeten dengan jumlah yang banyak dan didukung dengan sistem yang lebih canggih sehingga laporan auditan yang dihasilkan lebih akurat.

Teori agensi menjelaskan bahwa manajemen sebagai pengelola perusahaan memiliki kewajiban moral bertanggung jawab atas wewenang yang telah diberikan pemegang saham. Pertanggungjawaban manajemen dapat dinyatakan melalui laporan keuangan yang telah dibuat dan opini audit merupakan penilaian independen terhadap laporan keuangan. Pernyataan opini dari seorang auditor tersebut dapat memengaruhi pandangan pemegang saham mengenai kinerja manajemen dalam mengelola perusahaan. Oleh karena itu, manajemen cenderung untuk menghindari atau tidak menyukai qualified opinion. Jika perusahaan mendapatkan qualified opinion maka akan menurunkan kredibilitas laporan keuangan perusahaan. Hal ini didukung oleh hasil penelitian yang telah dilakukan oleh Aini (2019), Sari (2018) dan Karliana (2017) yang menyatakan bahwa opini audit berpengaruh positif pada auditor switching. Berdasarkan kajian teori dan empiris maka dapat dirumuskan hipotesis adalah sebagai berikut.

$\mathrm{H}_{1}$ : Opini audit berpengaruh positif pada auditor switching.

Pergantian manajemen yang baru dapat menimbulkan pemberlakuan kebijakan perusahaan yang baru salah satunya pemilihan KAP (Pradhana, 2015). Kebijakan baru yang diterapkan oleh direktur utama dapat memicu terjadinya 
pergantian auditor. Manajemen baru cenderung akan mencari auditor yang setuju dengan kebijakan baru yang diterapkan perusahaan. Penelitian yang dilakukan oleh Wulandari (2018) menyatakan bahwa pergantian manajemen berpengaruh positif pada auditor switching. Hal ini didukung oleh hasil penelitian yang telah dilakukan oleh Udayani (2017), Pawitri \& Yadnyana (2015), dan Pradhana (2015). Berdasarkan kajian teori dan empiris maka dapat dirumuskan hipotesis adalah sebagai berikut:

$\mathrm{H}_{2}$ : Pergantian manajemen berpengaruh positif pada auditor switching.

Reputasi auditor menunjukkan prestasi dan kepercayaan publik yang disandang auditor atas nama besar yang dimiliki auditor. Berdasarkan teori kontingensi, akibat adanya desakan lingkungan perusahaan, para pengguna laporan keuangan menganggap perusahaan yang besar akan menggunakan auditor yang mempunyai reputasi baik.Perusahaan cenderung menggunakan kantor akuntan publik yang berafiliasi dengan big four, karena kantor akuntan publik yang berafiliasi dengan big four memiliki indenpendensi dan kompetensi yang lebih baik dibandingkan kantor akuntan publik non big four. Penelitian yang dilakukan oleh Svanberg \& Öhman (2015) menyatakan bahwa pergantian auditor setelah penerbitan opini audit going concern dipengaruhi oleh reputasi auditor. Hal ini didukung oleh hasil penelitian yang telah dilakukan Robbitasari (2013), Setiyawan (2017) dan Sukadana (2016). Berdasarkan kajian teori dan empiris maka dapat dirumuskan hipotesis adalah sebagai berikut:

$\mathrm{H}_{3}$ : Reputasi auditor memperkuat pengaruh opini audit pada auditor switching.

Adanya pergantian manajemen akan menimbulkan adanya perubahan dalam pemberlakuan kebijakan perusahaan yang baru di bidang akuntansi, keuangan, dan termasuk kebijakan dalam menggunakan jasa kantor akuntan publik (KAP). Berdasarkan teori kontingensi, perbedaan desakan lingkungan perusahaan menjadi acuan pihak manajemen dalam memilih sistem akuntansi yang akan diberlakukan di perusahaan tersebut. Akibat dari desakan lingkungan perusahaan para pengguna laporan keuangan yang menganggap bahwa semakin bertumbuhnya sebuah perusahaan maka akan menggunakan auditor yang lebih baik dalam konteks reputasi. Perusahaan akan berusaha mencari auditor yang mampu sejalan dan sepakat dengan kebijakan akuntansi yang berlaku di perusahaan. Hasil penelitian dari Yuliani (2018), Saputra (2017), dan Wulandari (2018) menyatakan bahwa reputasi auditor tidak mampu memoderasi pergantian manajemen terhadap pergantian auditor dikarenakan adanya pergantian manajemen yang dilakukan oleh perusahaan akan menimbulkan kebijakan-kebijakan yang baru termasuk dalam pemilihan KAP maupun auditor. Apapun reputasi auditornya selama sesuai dengan keinginan manajemen, baik lama maupun baru maka auditor tersebut tidak akan diganti. Berdasarkan kajian teori dan empiris maka dapat dirumuskan hipotesis adalah sebagai berikut:

$\mathrm{H}_{4}$ : Reputasi auditor memperlemah pengaruh pergantian manajemen pada auditor switching.

\section{METODE PENELITIAN}

Penelitian ini menggunakan metode kuantitatif yang berbentuk asosiatif. Lokasi penelitian ini dilakukan pada perusahaan manufaktur yang terdaftar di Bursa 
Efek Indonesia (BEI) pada tahun 2014-2018 dengan mengakses ke situs www.idx.co.id. Obyek dari penelitian ini adalah auditor switching yang diukur dengan opini audit, pergantian manajemen dan reputasi auditor. Reputasi auditor dalam penelitian ini berfungsi sebagai pemoderasi pengaruh antara variabel dependen dengan independen.

Populasi pada penelitian ini adalah perusahaan manufaktur yang telah terdaftar di Bursa Efek Indonesia (BEI) pada tahun 2014-2018 yang berjumlah 141 perusahaan. Metode penentuan sampel yang digunakan dalam penelitian ini adalah metode probability sampling dengan teknik sampling yang digunakan adalah purposive sampling. Metode pengumpulan data yang digunakan adalah metode observasi non partisipan.

Penelitian ini menggunakan teknik analisis regresi logistik karena variabel dependen dalam penelitian ini yaitu auditor switching bersifat dikotomus atau merupakan variabel dummy. Tahapan dalam pengujian dengan menggunakan uji regresi logistik, yaitu menguji kelayakan model regresi (goodness of fit test), menilai keseluruhan model (overall model fit test), koefisien determinasi (nagelkerke $r$ square), matriks klasifikasi dan model regresi yang terbentuk. Penelitian ini juga menggunakan variabel moderasi. Cara pengujian variabel moderasi dalam penelitian ini menggunakan uji interaksi atau biasa disebut dengan Moderated Regression Analysis (MRA). Model regresi yang digunakan dalam penelitian ini ditunjukkan dalam persamaan sebagai berikut:

$\operatorname{Ln} \frac{p(\text { AS })}{1-P(A S)}=\alpha+\beta_{1} \mathrm{X}_{1}+\beta_{2} \mathrm{X}_{1} \cdot \mathrm{M}+\varepsilon$
$\mathrm{Ln} \frac{\boldsymbol{P}(\text { AS })}{1-P(A S)}=\alpha+\beta_{3} \mathrm{X}_{2}+\beta_{4} \mathrm{X}_{2} \cdot \mathrm{M}+\varepsilon$

Keterangan:

$$
\begin{array}{ll}
\operatorname{Ln} \frac{P(A S)}{1-P(A S)} & =\text { Auditor Switching } \\
\alpha & =\text { Konstanta } \\
\beta_{1}, \beta_{2}, \beta_{3} & =\text { Koefisien Regresi } \\
X_{1} & =\text { Opini Audit } \\
X_{2} & =\text { Pergantian Manajemen } \\
M & =\text { Reputasi Auditor } \\
\varepsilon & =\text { Error Term }
\end{array}
$$

\section{HASIL DAN PEMBAHASAN}

Penelitian ini dilakukan untuk mengetahui reputasi auditor sebagai pemoderasi pengaruh opini audit dan pergantian manajemen pada auditor switching. Berdasarkan data dari Bursa Efek Indonesia (BEI) pada tahun 2014-2018 terdapat 141 perusahaan manufaktur yang terdaftar selama periode tersebut. Proses seleksi sampel menggunakan teknik purposive sampling dengan kriteria yang ditetapkan dan terpilih sebanyak 29 perusahaan yang menjadi sampel dalam penelitian ini sehingga jumlah sampel yang digunakan dengan periode pengamatan 5 tahun yaitu dari tahun 2014 hingga 2018 adalah sebanyak 145 sampel penelitian.

Statistik deskriptif bertujuan untuk memberikan gambaran atau deskripsi tentang variabel-variabel penelitian dari suatu data.Berdasarkan pengolahan data SPSS didapatkan hasil analisis yang disajikan dalam Tabel 1. 
Tabel 1. Hasil Statistik Deskriptif

\begin{tabular}{lccccc}
\hline \multicolumn{1}{c}{ Variabel } & $\mathrm{N}$ & Minimum & Maksimum & Mean & $\begin{array}{c}\text { Std. } \\
\text { Deviasi }\end{array}$ \\
\hline Auditor Switching (Y) & 145 &, 00 & 1,00 & 0,50162 & 0,51034 \\
Opini Audit (X1) & 145 &, 00 & 1,00 & 0,33103 & 0,47221 \\
Pergantian Manajemen (X2) & 145 &, 00 & 1,00 & 0,35172 & 0,47916 \\
Reputasi Auditor (M) & 145 &, 00 & 1,00 & 0,48275 & 0,50143 \\
Valid N (listwise) & 145 & & & & \\
\hline
\end{tabular}

Sumber: Data Penelitian, 2020

Nilai minimum variabel auditor switching (AS) adalah 0, nilai maksimum sebesar 1, standar deviasi sebesar 0,51034, dan nilai rata-rata (mean) sebesar 0,50162. Nilai mean sebesar 0,50162 menunjukkan bahwa dari 145 sampel pengamatan, perusahaan yang melakukan pergantian auditor lebih sedikit dibandingkan dengan perusahaan yang tidak melakukan pergantian auditor.

Nilai minimum variabel opini audit adalah 0 , nilai maksimum sebesar 1 , standar deviasi sebesar 0,47221, dan nilai rata-rata (mean) sebesar 0,33103. Nilai mean sebesar 0,33103 menunjukkan bahwa dari 145 sampel pengamatan, perusahaan yang menerima opini audit selain wajar tanpa pengecualian lebih sedikit daripada perusahaan yang menerima opini wajar tanpa pengecualian.

Nilai minimum variabel pergantian manajemen adalah 0 , nilai maksimum sebesar 1, standar deviasi sebesar 0,47916, dan nilai rata-rata (mean) sebesar 0,35172. Nilai mean sebesar 0,35172 menunjukkan bahwa dari 145 sampel pengamatan, perusahaan yang melakukan pergantian manajemen lebih sedikit dibandingkan dengan perusahaan yang tidak melakukan pergantian manajemen.

Nilai minimum variabel reputasi auditor adalah 0 , nilai maksimum sebesar 1 , standar deviasi sebesar 0,50143, dan nilai rata-rata (mean) sebesar 0.48275 . Nilai mean sebesar 0,48275 menunjukkan bahwa dari 145 sampel pengamatan, perusahaan yang menggunakan KAP yang berafiliasi dengan big four lebih sedikit dibandingkan dengan perusahaan yang menggunakan KAP non big four.

Menilai Kelayakan Model Regresi dinilai dengan menggunakan uji Hosmer and Lemeshow's Goodness of Fit Test.Berikut disajikan tabel uji Hosmer and Lemeshow's Goodness of Fit Test.

Tabel 2. Hasil Uji Hosmer and Lemeshow's Test

\begin{tabular}{lcccc}
\hline & Step & Chi-Square & Df & Sig. \\
\hline Model 1 & 1 & 0,000 & 2 & 1,000 \\
Model 2 & 1 & 0,000 & 2 & 1,000 \\
\hline
\end{tabular}

Sumber: Data Penelitian, 2020

Pada model 1 uji Hosmer and Lemeshow's Goodness of Fit Test yang disajikan dapat dilihat bahwa nilai signifikansi uji Hosmer and Lemeshow sebesar 1,000. Nilai hasil uji lebih besar dari 0,05 sehingga hipotesis nol diterima yang berarti bahwa model mampu memprediksi nilai observasinya atau dapat dikatakan model dapat diterima karena cocok dengan data observasinya.

Pada model 2 nilai signifikansi uji Hosmer and Lemeshow sebesar 1,000 dimana nilai ini lebih besar dari 0,05 sehingga hipotesis nol diterima atau dapat dikatakan bahwa model mampu memprediksi nilai observasinya sehingga 
model dapat diterima. Berdasarkan hasil uji Hosmer and Lemeshow's Goodness of Fit Test pada kedua model, maka dapat disimpulkan bahwa kedua model dapat diterima.

Menilai Keseluruhan Model (Overall Model Fit) dilakukan untuk mengetahui apakah keseluruhan model sesuai dengan data. Hasil pengujian ditampilkan dalam Tabel 3, Berikut.

Tabel 3. Perbandingan -2 Log Liklehood Awal dan Akhir

\begin{tabular}{clc}
\multirow{2}{*}{ Model 1 } & -2LL awal (Block Number $=0)$ & 192,480 \\
& -2LL akhir (Block Number $=1)$ & 154,813 \\
\multirow{2}{*}{ Model 2 } & -2LL awal (Block Number $=0)$ & 192.480 \\
& -2LL akhir (Block Number $=1)$ & 152,329 \\
\hline
\end{tabular}

Sumber: Data Penelitian, 2020

Berdasarkan Tabel 3, dapat dilihat bahwa pada model 1, nilai -2LL awal sebesar 192,480 sementara nilai -2LL akhir sebesar 154,813. Nilai -2LL pada awal dan akhir menunjukkan penurunan sehingga berdasarkan data tersebut menunjukkan bahwa model regresi baik. Pada model 2, nilai -2LL juga mengalami penurunan dari nilai -2LL awal sebesar 192,480 menjadi 152,329 yang menunjukkan bahwa model regresi baik. Berdasarkan data tersebut maka dapat disimpulkan bahwa baik pada model 1 maupun model 2 keduanya merupakan model regresi yang baik atau merupakan model yang fit dengan data.

Besarnya nilai koefisien determinasi pada model regresi logistik ditunjukkan dengan nilai Nagelkerke's $R$ Square. Nagelkerke's $R$ Square digunakan untuk mengukur seberapa besar variabel bebas yang digunakan dalam penelitian ini mampu mempengaruhi variabel terikat. Berikut ini hasil pengujian koefisien determinasi (Nagelkerke's R Square) yang disajikan dalam Tabel 4.

Tabel 4. Hasil Uji Nagelkerke's R Square

\begin{tabular}{lcccc}
\hline & Step & -2 Log Likelihood & Cox $\mathcal{E}$ Snell R Square & Nagelkerke R Square \\
\hline Model 1 & 1 & 154,813 & 0,273 & 0,363 \\
Model 2 & 1 & 152,329 & 0,285 & 0,380 \\
\hline
\end{tabular}

Sumber: Data Penelitian, 2020

Berdasarkan Tabel 4 menunjukkan nilai Nagelkerke's $R$ Square sebesar 0,363 pada model 1 dan 0,380 pada model 2 . Hal ini berarti variabel bebas yaitu opini audit dan pergantian manajemen, serta variabel moderasinya yaitu reputasi auditor yang digunakan dalam penelitian ini mampu menjelaskan variabilitas variabel terikat yaitu auditor switching sebesar 36,3\% sedangkan $63,7 \%$ dijelaskan oleh variabel lain yang tidak dimasukkan dalam penelitian ini pada model 1 . Sementara pada model 2 variabel bebas dan variabel moderasi dapat menjelaskan variabilitas variabel terikat sebesar $38 \%$ sementara $62 \%$ dijelaskan oleh variabel lain yang tidak dimasukkan dalam penelitian ini.

Hasil pengujian menunjukkan kekuatan prediksi dari model regresi 1 dan 2 untuk memprediksikan kemungkinan perusahaan tidak melakukan auditor switching adalah sebesar $73,8 \%$. Sehingga dapat diketahui bahwa dengan menggunakan model regresi tersebut, terdapat 97 sampel pengamatan yang tidak melakukan auditor switching dan 48 sampel pengamatan yang melakukan auditor switching dari total 145 sampel pengamatan.Berdasarkan hasil analisis dengan menggunakan program SPSS 17 maka diperoleh hasil berikut. 
Tabel 5. Hasil Uji Koefisien Regresi

\begin{tabular}{lllcccccc}
\hline & & & $B$ & S.E. & Wald & Df & Sig. & $\operatorname{Exp}(B)$ \\
\hline \multirow{2}{*}{ Model } & Step & X1 & 2,803 & 0,587 & 22,771 & 1 & 0,000 & 16,500 \\
1 & & X1.M & 18,902 & 13397,657 & 0,000 & 1 & 0,999 & 2,008 \\
& \multirow{2}{*}{ Step } & Constant & $-1,099$ & 0,385 & 8,147 & 1 & 0,004 & 0,333 \\
Model & 1 & X2 & 2,788 & 0,684 & 16,623 & 1 & 0,000 & 16,250 \\
2 & & X2.M & 0,048 & 0,979 & 0,002 & 1 & 0,961 & 1,049 \\
& & Constant & $-0,629$ & 0,310 & 4,123 & 1 & 0,042 & 0,533 \\
\hline
\end{tabular}

Sumber: Data Penelitian, 2020

Berdasarkan Tabel 5, diperoleh persamaan regresi sebagai berikut.

$$
\begin{aligned}
& \operatorname{Ln} \frac{P(A S)}{1-P(A S)}=-1,099+2,803 X 1+18,902 X 1 . M_{1}+e \\
& \operatorname{Ln} \frac{P(A S)}{1-P(A S)}=-0,629+2,788 X 2+0,048 X 2 . M_{1}+e
\end{aligned}
$$

Hasil pengujian dengan menggunakan regresi logistik menunjukkan nilai koefisien positif sebesar 2,803 dengan signifikansi 0,000 dimana nilai ini lebih kecil dibandingkan $\alpha=5 \%(0,000<0,05)$. Sehingga dapat diinterpretasikan bahwa variabel opini audit berpengaruh positif pada auditor switching. Dalam teori agensi menjelaskan bahwa manajemen sebagai pengelola perusahaan memiliki kewajiban moral bertanggung jawab atas wewenang yang telah diberikan pemegang saham. Pertanggungjawaban manajemen dapat dinyatakan melalui laporan keuangan yang telah dibuat dan opini audit merupakan penilaian independen terhadap laporan keuangan. Pernyataan opini dari seorang auditor tersebut dapat memengaruhi pandangan pemegang saham mengenai kinerja manajemen dalam mengelola perusahaan. Oleh karena itu, manajemen cenderung untuk menghindari atau tidak menyukai opini selain opini wajar tanpa pengecualian.

Dwiphayana (2019) menyatakan bahwa perusahaan cenderung berganti auditor atau berpindah KAP setelah menerima qualified opinion atas laporan keuangannya. Jadi, dapat disimpulkan bahwa klien yang mendapat opini yang tidak diharapkan atas laporan keuangannya akan cenderung mengganti auditornya. Hal ini disebabkan karena perusahaan menghindari munculnya qualified opinion dalam laporan keuangan mereka. Jika perusahaan mendapatkan qualified opinion maka akan menurunkan kredibilitas laporan keuangan perusahaan serta dianggap akan memberikan respon negatif pada harga saham. Hal tersebut menyebabkan manajemen perusahaan akan memberhentikan auditornya karena memberikan opini audit yang tidak sesuai dan akan mencari auditor yang lebih mudah diatur.Hasil penelitian ini didukung oleh penelitian Aini (2019), Luthfiyati (2016), dan Karliana (2017) yang menyatakan bahwa opini audit berpengaruh positif pada auditor switching.

Hasil pengujian dengan menggunakan regresi logistik menunjukkan nilai koefisien positif sebesar 2,788 dengan signifikansi 0,000 dimana nilai ini lebih kecil dibandingkan $a=5 \%(0,000<0,05)$. Sehingga dapat diinterpretasikan bahwa variabel pergantian manajemen berpengaruh positif pada auditor switching. Hasil penelitian ini sejalan dengan teori keagenan yang menyebutkan adanya perbedaan kepentingan dan tujuan antara prinsipal dengan agen yang 
memicu timbulnya agency problem. Adanya konflik ini dikarenakan pihak manajemen yang berperan sebagai agen memiliki kepentingan pribadinya dalam menjalankan perusahaan sehingga kepentingan dari pemegang saham yang merupakan pemilik perusahaan tidak dapat dicapai. Hal ini membuat prinsipal kehilangan kepercayaan kepada agen dan memilih untuk mangganti manajemen perusahaan. Adanya perbedaan kepentingan tersebut rentan menimbulkan konflik, terjadinya konflik cenderung menyebabkan manajemen diganti dan pergantian manajemen diikuti dengan pergantian auditor.

Penelitian ini mendukung hasil penelitian yang dilakukan oleh Saputra (2017), Pradhana (2015), dan Wulandari (2018) yang menyatakan perusahaan dalam mengubah jajaran direksi, baik itu direktur, direksi ataupun komisarisnya, akan memicu beberapa perubahan dan penyesuaian dalam sisi kebijakan yang diterapkan oleh perusahaan di bidang keuangan, akuntansi, dan dalam pemilihan auditor.Perusahaan cenderung mencari auditor yang sejalan dengan seluruh kebijakan baru yang berlaku di perusahaan tersebut. Pihak manajemen tentunya memerlukan kualitas audit yang lebih baik sehingga ada kemungkinan jika perusahaan cenderung mangganti auditornya.

Hasil pengujian menggunakan regresi logistik menunjukkan nilai koefisien positif sebesar 18,902 dengan tingkat signifikansi 0,999 pada variabel interaksi antara opini audit dan reputasi auditor pada auditor switching. Nilai signifikansi lebih besar dari $\alpha=5 \%(0,999>0,05)$. Sehingga dapat diinterpretasikan bahwa reputasi auditor tidak mampu memoderasi pengaruh opini audit pada auditor switching. Hal ini tidak sejalan dengan teori kontingensi yang menyatakan akibat desakan lingkungan perusahaan, para pengguna laporan keuangan menganggap perusahaan besar pasti akan menggunakan auditor yang mempunyai reputasi baik. Perusahaan cenderung menggunakan kantor akuntan publik yang berafiliasi dengan big four, karena kantor akuntan publik yang berafiliasi dengan big four memiliki indenpendensi dan kompetensi yang lebih baik dibandingkan kantor akuntan publik non big four.

Penelitian ini mendukung hasil penelitian yang dilakukan oleh Putri (2018) dan Huda (2018) yang menyatakan bahwa pergantian auditor setelah penerbitan opini audit yang tidak sesuai dengan keinginan perusahaan tidak dipengaruhi oleh reputasi auditor. Perusahaan yang sudah menerima opini yang sesuai dengan keinginannya cenderung tidak akan melakukan auditor switching walaupun perusahaan tersebut tidak menggunakan kantor akuntan publik yang berafiliasi dengan big four.

Hasil pengujian menggunakan regresi logistik menunjukkan nilai koefisien positif sebesar 0,048 dengan tingkat signifikansi 0,999 pada variabel interaksi antara pergantian manajemen dan reputasi auditor pada auditor switching. Nilai signifikansi lebih besar dari $\alpha=5 \%(0,961>0,05)$. Sehingga dapat diinterpretasikan bahwa reputasi auditor tidak mampu memoderasi pengaruh pergantian manajemen pada auditor switching. Hasil penelitian ini tidak sejalan dengan teori kontingensi yang menyatakan perbedaan desakan lingkungan perusahaan menjadi acuan pihak manajemen dalam memilih sistem akuntansi yang akan diberlakukan di perusahaan tersebut. Akibat dari desakan lingkungan perusahaan, para pengguna laporan keuangan 
menganggap bahwa semakin bertumbuhnya perusahaan maka akan menggunakan auditor yang lebih baik dalam konteks reputasi.

Penelitian ini mendukung hasil penelitian yang dilakukan oleh Wulandari (2018), Saputra (2017), dan Yuliani (2018) menyatakan bahwa reputasi auditor tidak mampu memoderasi pergantian manajemen terhadap pergantian auditor. Hal ini dikarenakan manajemen yang baru dalam melakukan pemilihan KAP akan melakukan pertimbangan kembali untuk tidak melakukan pergantian KAP ketika melihat reputasi yang dihasilkan dari KAP sebelumnya. Manajemen baru akan melihat reputasi dari KAP sebelumnya dari seberapa banyak KAP tersebut memiliki klien terkait industri yang dipimpinnya. Apapun reputasi auditornya selama sesuai dengan kebijakan manajemen maka maka auditor tersebut tidak akan diganti.

\section{SIMPULAN}

Opini audit berpengaruh positif pada auditor switching. Hal ini berarti semakin sering perusahaan memperoleh opini audit diluar opini wajar tanpa pengecualian maka perusahaan cenderung akan melakukan auditor switching. Pergantian manajemen berpengaruh positif pada auditor switching. Hal ini berarti bahwa perusahaan yang mengalami pergantian manajemen mengakibatkan perubahan pada kebijakan di dalam perusahaan seperti dalam bidang akuntansi, keuangan, dan juga pemilian akuntan publik atau kantor akuntan publik (KAP) dibandingkan dengan perusahaan yang tidak mengalami pergantian manajemen. Reputasi auditor tidak mampu memoderasi pengaruh opini audit pada pergantian auditor. Hal ini berarti bahwa reputasi apapun yang dimiliki auditor selama dapat memberikan opini yang diharapkan oleh perusahaan maka auditor tersebut tidak akan diganti. Reputasi auditor tidak mampu memoderasi pengaruh pergantian manajemen pada auditor switching. Hal ini berarti bahwa reputasi apapun yang dimiliki auditor apabila sesuai dengan kebijakan manajemen maka maka auditor tersebut tidak akan diganti.

Bagi kantor akuntan publik yang berafiliasi dengan big four maupun yang tidak berafiliasi dengan big four diharapkan mampu mempertahankan independensi dan meningkatkan kualitas audit yang dihasilkan, sehingga mampu memberikan jaminan akan kewajaran laporan keuangan suatu entitas. Peneliti selanjutnya diharapkan untuk mengkaji lebih banyak sumber maupun referensi terkait opini audit, pergantian manajemen, reputasi auditor dan auditor switching agar hasil penelitian berikutnya dapat menjadi lebih baik dan lebih lengkap serta disarankan untuk menggunakan variabel-variabel lain yang dapat menyempurnakan penelitian dengan topik yang sama.

\section{REFERENSI}

Abdul Nasser, A. T., Abdul Wahid, E., Mustapha Nazri, S. N. F. S., \& Hudaib, M. (2006). Auditor-client relationship: The case of audit tenure and auditor switching in Malaysia. Managerial Auditing Journal, 21(7), 724-737. https:// doi.org/10.1108/02686900610680512

Agiastuti, I., \& Dharma Suputra, I. (2016). Faktor-Faktor Yang Berpengaruh Pada Voluntary Auditor Switching. E-Jurnal Akuntansi, 17(1), 56-83. 
Aini, N., \& Yahya, M. R. (2019). Pengaruh Management Change, Financial Distress, Ukuran Perusahaan Klien, Dan Opini Audit Terhadap Auditor Switching. Jurnal Ilmiah Mahasiswa Ekonomi Akuntansi, 4(2), 245-258. https:// doi.org/10.24815/jimeka.v4i2.12235

AlAzhar L. (2015). Influence of Financial Distress, Management Turnover and Audit Opinion to Auditor Switching (Empirical Study on Manufacturing Companies Listed on The BEI During 2011-2013 Period). Research Journal of Finance and Accounting, 6(24).

Ali, K. H. (2015). Determinants of Auditor Switching in Bahraini'S Listed Companies - an Empirical Study. European Journal of Accounting, Auditing and Finance Research, 3(11), 73-99.

Bayu Pradhana, M., \& Dharma Suputra, I. (2015). Pengaruh Audit Fee, Going Concern, Financial Distress, Ukuran Perusahaan, Pergantian Manajemen Pada Pergantian Auditor. E-Jurnal Akuntansi, 11(3), 713-729.

Blouin, J., Grein, B.M., and Rountree, B.R. (2007). An Analysis of Forced Auditor Change: The Case of Former Arthur Andersen Clients. The Accounting Review. Vol. 82. pp.621-650. https:// doi.org/10.2308/accr.2007.82.3.621

Cameran, M., Prencipe, A., \& Trombetta, M. (2016). Mandatory Audit Firm Rotation and Audit Quality. European Accounting Review, 25(1), 35-58. https://doi.org/10.1080/09638180.2014.921446

Carcello, J. V. dan T.L. Neal. 2003. Audit Committee Characteristics and Auditor Dismissals Following New Going Concern Reports. The Accounting Review, 78(1). https://doi.org/10.2308/accr.2003.78.1.95

Chadegani, A. A., Mohamed, Z. M., \& Jari, A. (2011). The Determinant Factors of auditor switch among companies listed on Tehran Stock Exchange. International Research Journal of Finance and Economics, 80(May 2014), 159-167.

Chang, W. C., Choy, H. L., Lin, H. Y., \& Koo, M. (2019). The Determinants and Effects of Clients Following Audit Partners Who Switch Audit Firms. European Accounting Review, 28(3), 541-571. https:// doi.org/10.1080/09638180.2018.1509014

Chow, CW, dan Rice SJ. (1982). Qualified Audit Opinion and Auditor Switching. The Accounting Review. The Accounting Review, vol LVII.

Chi, W., Huang, H., Liao, Y., and Xie, H. (2009). Mandatory Audit Patner Rotation, Audit Quality, and Market Perception: Evidence from Taiwan. Contemporary Accounting Research. $26 . \quad$ pp.359-391. https:// doi.org/10.1506/car.26.2.2

Deng, M., Li, J., Simunic, D. A., \& Zhou, N. (2019). Audit Retendering and Mandatory Auditor Rotation. SSRN Electronic Journal. https://doi.org/10.2139/ssrn.3444676

Dwiphayana, G. N. M., \& Suputra, I. D. G. D. (2019). Pengaruh Opini Audit dan Audit Delay Pada Auditor Switching dengan Karakteristik Komite Audit Sebagai Pemoderasi. E-Jurnal Akuntansi Universitas Udayana, 28(3), 19651983. https:// doi.org/10.24843/EJA.2019.v28.i03.p21.

Fajrin, F. (2015). Pengaruh Diferensi Kualitas Audit, Kesulitan Keuangan Perusahaan, Opini Audit, Kepemilikan Institusional, dan Fee Audit terhadap Pergantian KAP. Jom FEKON, 2,1-13 
Gammal, W, E. (2012). Determinants of Audit Fees: Evidence from Lebanon. Journal International Business Research, 5 (11), pp.136-143. http://dx.doi.org/10.5539/ibr.v5n11p136

Hudaib, M. dan T.E. Cooke. (2005). The Impact of Managing Director Changes and Financial Distress on Audit Qualification and Auditor Switching. Journal of Business Finance \& Accounting. Vol. 32. https://doi.org/10.1111/j.0306686X.2005.00645.x

Indah Sari, I., \& Widanaputra, A. (2016). Reputasi Auditor Sebagai Pemoderasi Pengaruh Audit Fee Pada Auditor Switching. E-Jurnal Akuntansi, 16(1), 527556.

Institut Akuntan Publik Indonesia. (2016). Standar Profesional Akuntan Publik. Jakarta:Salemba Empat. (hal.341.2)

Ismail, Shahnaz (2008). Why Malaysian Second Board Companies Switch Auditors? Evidence of Bursa Malaysia. International Research Journal of Finance and Economics. ISSN 1450-2887 Issue 13.

Jackson, A.B., Moldrich, M. and Roebuck, P. (2008). Mandatory Audit Firm Rotation and Audit Quality. Managerial Auditing Journal, 23 (5), pp.420-437.

Karliana dkk, D. R. (2017). Pengaruh Opini Audit, Reputasi Auditor dan Audit Fee terhadap Auditor Switching (Studi pada Perusahaan Sektor Infrasrtuktur, Utilitas, dan Transportasi yang Terdaftar di Bursa Efek Indonesia Tahun 2010-2015). E-Proceeding of Management, 4(2), 1740-1745.

Khoirul Huda. (2018). Pengaruh Opini Audit Going Concern, Audit delay, dan Audit Fee terhadap Auditor Switching dengan Reputasi Auditor sebagai Variabel Pemoderasi. Skripsi. Fakultas Ekonomi dan Bisnis Universitas Muria Kudus

Lin, Z. J., \& Liu, M. (2010). The determinants of auditor switching from the perspective of corporate governance in China. Advances in Accounting, 26(1), 117-127. https:/ / doi.org/10.1016/j.adiac.2010.03.001

Luthfiyati, B. (2016). Pengaruh Ukuran Perusahaan, Opini Audit, Pergantian Manajemen, Ukuran KAP, dan Audit Tenure Terhadap Auditor Switching. Jurnal of Accounting, 2(2), 52-65.

Mohamed, D. M. dan M. H. Habib. (2013). Auditor Independence, Auditor Quality and the Mandatory Auditor Rotation in Egypt. Education, Business and Society: Contemporary Middle Eastern Issues. 6 (2), p. https://doi.org/10.1108/EBS-07-2012-0035

Mulyadi. (2016). Sistem Akuntansi. Jakarta: Salemba Empat.

Nyakuwanika, M. (2014). Why Companies Change Auditors in Zimbabwe? (2003-2013). Research Journal of Finance and Accounting Www.Iiste.Org ISSN, 5(5), 171-181.

Pawitri, N., \& Yadnyana, K. (2015). Pengaruh Audit Delay, Opini Audit, Reputasi Auditor Dan Pergantian Manajemen Pada Voluntary Auditor Switching. EJurnal Akuntansi, 10(1), 214-228.

Putra, I. G. B. B. P., \& Suryanawa, I. K. (2016). Pengaruh Opini Audit Dan Reputasi Kap Pada Auditor Switching Dengan Financial Distress Sebagai Variabel Moderasi. E-Jurnal Akuntansi Universitas Udayana, 14(2), 1120-1149.

Putri, K. O. (2018). Pengaruh Opini Audit Going Concern Dan Audit Delay Terhadap Auditor Switching Dengan Reputasi Kap Sebagai Variabel 
Moderasi. Skripsi. Fakultas Ekonomi dan Bisnis Universitas Muhammadiyah Surakarta

Robbitasari, A. P. (2013). Pengaruh Opini Audit Going Concern, Kepemilikan Institusional, dan Audit Delay pada Voluntary Auditor Switching. Jurnal Akuntansi Dan Bisnis, 5(3): 652-.

Saputra, G. (2017). Pengaruh Opini Going Concern dan Pergantian Manajemen Terhadap Auditor Switching, Reputasi Auditor Sebagai Variabel Moderating. JOM Fekon, 4(1), 3256-3268.

Sari, F. F. (2018). Pengaruh Opini Audit, Financial Distress, Perubahan Roa, dan Pertumbuhan Perusahaan Klien Terhadap Auditor Switching (Studi Pada Perusahaan Manufaktur Yang Terdaftar di Bursa Efek Indonesia Tahun 2011-2016). Skripsi. Fakultas Ekonomi Universitas Islam Indonesia

Setiyawan, A. (2017). Pengaruh Audit Fee dan Opini Audit Going Concern terhadap Auditor Switching dengan Reputasi KAP sebagai variabel moderasi. Skripsi. Fakultas Ekonomi dan Bisnis Universitas Muria Kudus

Sima, P. A. P., \& Badera, I. D. N. (2018). Reputasi Auditor sebagai Pemoderasi Pengaruh Financial Distress dan Audit Fee pada Auditor Switching. E-Jurnal Akuntansi, 24, 58. https://doi.org/10.24843/ eja.2018.v24.i01.p03

Standar Profesi Akuntan Publik. (2016). Jakarta: Salemba Empat.

Sukadana, I. dewa M., \& Wirakusuma, M. G. (2016). Reputasi Kantor Akuntan publik Memoderasi Opini Audit Going Concern dan Audit Delay Terhadap Audit Switching. E-Jurnal Akuntansi Udayana, 16(2), 1604-1634.

Svanberg, J., \& Öhman, P. (2014). Lost revenues associated with going concern modified opinions in the Swedish audit market. Journal of Applied Accounting Research, 15(2), 197-214. https:// doi.org/10.1108/JAAR-11-2012-0077

Tisna, N. W. W., \& Suputra, I. D. G. D. (2017). Financial Distress Sebagai Pemoderasi Pengaruh Opini Audit Dan Pertumbuhan Perusahaan Pada Auditor Switching. E-Jurnal Akuntansi, 19, 2118-2144.

Udayani, N. K. S., \& Badera, I. D. N. (2017). Kualitas Audit Sebagai Pemoderasi Pengaruh Pergantian Manajemen Dan Audit Fee Pada Auditor Switching. E-Jurnal Akuntansi, 20, 1820-1847.

Widyanti, A. A. S. I. A., \& Badera, I. D. N. (2016). Reputasi Auditor Sebagai Pemoderasi Pengaruh Financial Distress pada Auditor Switching. Jurnal Akuntansi Universitas Udayana, 16.3, 1800-1828.

Wijaya, E., \& Rasmini, N. (2015). Pengaruh Audit Fee, Opini Going Concern, Financial Distress, Ukuran Perusahaan, Ukuran Kap Pada Pergantian Auditor. E-Jurnal Akuntansi, 11(3), 940-966.

Wulandari, M. Widi, \& Suputra, I. D. G. D. (2018). Pengaruh Pergantian Manajemen dan Audit Fee pada Auditor Switching Dengan Reputasi Auditor Sebagai Variabel Pemoderasi. Jurnal Akuntansi Dan Bisnis. 25, 581605. https://doi.org/10.24843/EJA.2018.v25.i01.p22.

Yuliani, R., Sukarmanto, E., \& Purnamasari, P. (2018). Pengaruh Pergantian Manajemen dan Audit Delay terhadap Pergantian KAP dengan Reputasi KAP sebagai Variabel Moderasi ( Studi Empiris Pada Perusahaan yang Masuk Dalam Indeks LQ45 di Bursa Efek Indonesia Tahun 2013-2016 ). Prosiding Akuntansi, 262-268.

Yunawati, S., \& Zulkarnain, Z. (2019). The Determinant Factors of Auditor Switch 
(Empirical studies to Companies listed on Indonesian Stock Exchange). International Journal on Advanced Science, Education, and Religion, 2(2), 9-16. https:// doi.org/10.33648/ijoaser.v2i2.31 